\title{
Stem cell transplant and the potential role of CAR-T cells in multiple myeloma
}

\author{
Nouran Sabbagh ${ }^{1}$, Axel R. Zander ${ }^{2,3}$ \\ ${ }^{1}$ Alfaisal University, Riyadh, KSA \\ ${ }^{2}$ Department of Stem Cell Transplant, Huntsman Cancer Center Institute, SLC, USA \\ ${ }^{3}$ University of Hamburg, Germany
}

Professor Dr. Axel Zander, MD

Martinistr. 52, University of Hamburg, Germany
Phone: +491713135984

E-mail: axel.zander@hsc.utah.edu

Citation: Sabbagh N, Zander AR. Stem cell transplant and the potential role of CAR-T cells in multiple myeloma. Cell Ther Transplant 2018; 7(4): 8-15

\section{Summary}

Multiple myeloma is still an incurable cancer notwithstanding the myriads of chemo-and immunotherapies, There are more than 20,000 cases of MM diagnosed per year in the US. Bone marrow transplant is still considered the cornerstone for MM therapy, at least for now. The evident need is to revisit the conventional treatment approaches to cellular therapy, such as auto- and/or allogeneic hematopoietic stem cell transplantation (HCT), and develop the new options, like CAR-T cells. This review article will present and discuss different approaches to modern treatment of MM, by summarizing the results of clinical studies, raising feasibility and efficiency questions, and answering some of them which have been already resolved in numerous trials performed with CAR-T cells.

\section{Keywords}

Multiple myeloma, allogeneic transplant, autologous transplant, CAR-T cells.

\section{Multiple Myeloma and the role of transplant}

Multiple myeloma is proliferation of malignant plasma cells, resulting in overproduction of monoclonal proteins. It is the second most common hematologic malignancy in the USA [1], and it had long been considered a cancer with poor prognosis. At the present time, long-term survival of 5 and 10 years is possible, due to improvement of chemotherapy protocols and development of ground-breaking immunotherapy. This trend allowed many hematologists to avoid allogeneic bone marrow transplant in a number of patients. Lenalidomide, bortezomib and newer drugs have proven their efficacy in treating MM, but a subset of patients develops resistance to this treatment.

Autologous stem cell transplantation (auto-HCT) is an integrated part of most treatment strategies. Allogeneic stem cell transplantation (allo-HCT) is still a controversial option because of increased transplant-related mortality rates (TRM). Meanwhile, some doctors prefer allogeneic grafting rather than autologous transplantation in relapse of
MM, due to long-term disease-free survival associated with allo-HCT. Some factors like chemosensitivity and karyotype influence allogeneic transplant overall survival (OS) while donor availability influence progression free survival (PFS) [2]. Its curative potential is linked to graft-versus-host disease (GVHD), a side effect of allo-HCT which may be exploited for attacking any residual tumor cells. Moreover, the $\mathrm{T}$ cells with chimeric antigenic receptors (CAR-T cells) are regarded as the tools for making hematologic malignancies curable within next decade. The question still exists, whether allogeneic transplant will be used as a treatment modality for MM when implementing relatively more safe immune therapy options, like CAR-T cells.

\section{Autologous transplant, an old work-horse}

Autologous hematopoietic stem cell transplantation (autoHCT) was first introduced in the 80 s as an innovative treatment, being a preferred cellular treatment available for MM therapy. It has some advantages over allogeneic BMT and is still considered a safer option. The absence of immunolog- 
ical complications, like rejection and graft versus host disease (GVHD) is a major benefit, but the treatment-related toxicity cannot be overlooked. Despite multiple novel agents being developed, melphalan is still the main drug used for conditioning in the absence of other less toxic alternatives. Several alternative conditioning regimens have been studied but did not show superiority [3]. One exception may be Bendamustine, but this has not been fully explored yet [4]. Several other agents like idarubicin, etoposide, busulfan, carmustine and bortezomib were also studied as a substitute for melphalan, while none of them was shown to be superior [5], some were even more toxic than melphalan alone [6, $7]$, and recent studies comparing melphalan and carmustine did not show any difference in terms of TRM $[8,9]$. Furthermore, there is no universal consensus, when it comes to choice of the treatment modalities. E.g., one school recommends early double autologous transplant as based on trials that found considerable difference in 7-year overall survival (OS) between single vs double autologous SCT (42 vs 21\% respectively) bearing in mind the low progression-free survival (PFS) in both groups (23\% vs $13 \%$ respectively) [10]. Meanwhile, other workers suggest performing it as salvage treatment to allow for longer remission. Some authors claim that this strategy can lead to shorter period of disease control and carries the risk of doubling mutations over time and, consequently, increasing drug resistance of MM cells [11]. Other workers believe that salvage therapy is still acceptable, but under certain circumstances, particularly in patients with PFS $>12$ months, with first remission of less than 2 years duration [12].

Tandem ASCT had the rationale to avoid this possible clonal evolution. Total therapy 1 (TT1), the first tandem ASCT trial for newly diagnosed MM patients showed encouraging results. Consequently, TT II and III showed further improvement of the long-term PFS and OS survival [13].

\section{Allogeneic Transplant}

Allogeneic transplant is associated with sufficient TRM incidence. With introduction of reduced-intensity conditioning (RIC), the TRM rates could be reduced, but relapse has become a prominent problem [14]. Bensinger et al. in their retrospective review have reported a reduced TRM rate following RIC regimen, with HR of 0.22 (0.1-0.4) $\mathrm{P}<0.001$, and CR $38 \%$ vs $23 \%$ when comparing to those who received myeloablative conditioning [15]. RIC regimen showed lower TRM, but similar OS rate, due to lower PFS values. A relation was found between aGVHD and non-relapse mortality (NRM) at 2 years post transplant (24\% vs 37\%), and both conditions were less common in patients who received RIC treatment, despite higher incidence of chronic GVHD in RIC. Further modification of the conditioning regimen by retaining its intensity and reducing the toxicity did improve the outcome significantly [16].

The two main indications for allogeneic transplants were considered, i.e., salvage therapy after failed autologous transplant, or its usage as a part of tandem auto-allo-HCT protocols in the newly diagnosed patients $[17,18,20]$. The first approach was found to be associated with prolonged remission in multiple studies. In a prospective study conducted by Lav- allade et al. PFS was significantly higher in allogeneic HCT group as compared to the patients who received standard therapy following failed autologous transplant [19]. A similar result was also found for the high-risk patients in a retrospective study conducted by Nair, especially with lower dose of CD3+ cells infused [21]. In CIBMTR Registry, the salvage allograft patients were compared to double autotransplant cohort between 1995-2008 with inferior results, including rate of progression, observed in the salvage allograft group. In another study, when comparing 169 relapsed patients after autotransplant, PFS was higher in allograft group but with higher NRM and similar OS rates (54\% vs 53\%) [22].

Some studies, however, believe that careful donor selection may improve survival in relapsed patients [21, 23], though other options are suggested by the more recent studies [24]. Donato et al. did not find statistically significant difference in cGVHD rates between related and unrelated donor group, but higher aGVHD incidence in HCTs from unrelated donors $[25,26]$.

Concerning allo-SCT as a part of tandem transplant, there is still no consensus on whether it is superior to the tandem ASCT or single auto-HCT. When comparing allo-auto with tandem auto-HCT, Krishnan et al. did not find better overall survival (OS) or progression-free-survival (PFS) with tandem allo-auto transplant at 3 years [27]. Among several prospective trials comparing the both treatment approaches, the three programs performed by Italian, EBMT, and DSMM working groups have revealed higher efficiency, in terms of OS and PFS for those patients who underwent allo-SCT [26].

So far, the Blood and Marrow Transplant Clinical Trials Network (BMT CTN) has performed the largest trial which showed a weak trend for longer OS and PFS in the patients who underwent tandem ASCT, over those who had tandem auto/allo-HCT, but the results did not reach statistical significance. I.e., the respective PFS rates were $46 \%$ vs $43 \%$ $(\mathrm{P}=0.67)$, and $\mathrm{OS}$ values comprised $80 \%$ vs $77 \%$, respectively $(\mathrm{P}=0.19)$ [28]. Bjorkstrand et al. believe that this disparity in the results can be due to differences in conditioning regimen used [29]. The results of extensive available to date are summarized in Table 1.

Disappointing results of early comparative studies seem to be more encouraging with longer follow-up. Shimoni et al. claim that most studies supporting benefits of autologous over allogeneic transplant, do not necessarily reflect accurate results, since the follow-up period is short (an average of 3 yrs), and allogeneic transplants require longer follow-up period to show the PFS plateau [35]. In his study, the PFS plateau was seen after median of 6 years of follow-up with $26 \%$ PFS and $34 \%$ OS out of 50 patients. Similar results were found by El-Cheikh et al [25] at a wider age range (28-70 y.o.), with OS and PFS of $32 \% \& 24 \%$, respectively. Kröger et al [23] attributes this skepticism and high-failure rates of allogeneic SCT to potential inexperience and poor selection of unrelated donors for patients. In a prospective study, 95\% OR and 46\% CR rates are reported following allogeneic transplant with melphalan/fludarabine-based regimen. However, PFS and OS did not differ from those reported in patients who were treated with lenalidomide and dexamethasone, and this is likely due to high NRM revealed $(25 \%$ at 
Table 1. Summary of results on clinical outcomes in several studies comparing auto- and allo-SCT strategies in myeloma treatment

\begin{tabular}{|c|c|c|c|c|c|c|c|}
\hline $\begin{array}{l}\text { Clinical Trial, Pts } \\
\text { group, graft origin }\end{array}$ & Conditioning regimens & $\begin{array}{l}\text { Number } \\
\text { of cases }\end{array}$ & TRM & CR & DFS & OS levels & Reference \\
\hline $\begin{array}{l}\text { IFM } \\
\text { (high risk group) }\end{array}$ & $\begin{array}{l}\text { Auto: Mel200/220 mg/m² } \\
\text { Allo: Mel200 } \rightarrow \text { Bu/Flu/ATG }\end{array}$ & $\begin{array}{l}219 \\
65\end{array}$ & $\begin{array}{l}5 \% \\
11 \%\end{array}$ & $\begin{array}{l}33 \% \\
33 \%\end{array}$ & $\begin{array}{l}0 \%(5 y) \\
0 \%(5 y)\end{array}$ & $\begin{array}{l}44 \%(5 y) \\
33 \%(5 y)\end{array}$ & [30] \\
\hline $\begin{array}{l}\text { Italy } \\
\text { all cases: } \\
\text { HLA-identical }\end{array}$ & $\begin{array}{l}\text { Auto: Mel200 mg/m² } \\
\text { Allo: Mel200 } \rightarrow 2 \text { Gy TBI }\end{array}$ & $\begin{array}{l}80 \\
80\end{array}$ & $\begin{array}{l}4 \% \\
10 \%\end{array}$ & $\begin{array}{l}26 \% \\
53 \%\end{array}$ & $\begin{array}{l}20 \%(4 y) \\
42 \%(4 y)\end{array}$ & $\begin{array}{l}53 \%(4 y) \\
75 \%(4 y)\end{array}$ & [31] \\
\hline $\begin{array}{l}\text { Spain } \\
\text { all cases: } \\
\text { HLA-identical }\end{array}$ & $\begin{array}{l}\text { Auto: Bu-Mel/Mel/CBV } \\
\text { Allo: Flu/Mel140 }\end{array}$ & $\begin{array}{l}88 \\
26\end{array}$ & $\begin{array}{l}5 \% \\
16 \%\end{array}$ & $\begin{array}{l}11 \% \\
33 \%\end{array}$ & $\begin{array}{l}\text { med: } 30 \mathrm{~m} \\
\text { med } 19 \mathrm{~m}\end{array}$ & $\begin{array}{l}\text { med: } 57 \mathrm{~m} \\
\text { med: } \mathrm{n.r} .\end{array}$ & [3] \\
\hline $\begin{array}{l}\text { HOVON } \\
\text { all cases: } \\
\text { HLA-identical }\end{array}$ & $\begin{array}{l}\text { Auto: Mel200/FN vs Thal } \\
\text { Auto: Mel } \rightarrow 2 \mathrm{~Gy} \text { TBI }\end{array}$ & $\begin{array}{l}141 \\
126\end{array}$ & $\begin{array}{l}\text { nv } \\
14 \%\end{array}$ & $\begin{array}{l}42 \% \\
45 \%\end{array}$ & $\begin{array}{l}\text { med: } 30 \mathrm{~m} \\
\text { med } 30 \mathrm{~m}\end{array}$ & $\begin{array}{l}\text { med: } 60 \mathrm{~m} \\
\text { med: } 50 \mathrm{~m}\end{array}$ & [32] \\
\hline $\begin{array}{l}\text { EBMT } \\
\text { all cases: } \\
\text { HLA-identical }\end{array}$ & $\begin{array}{l}\text { Auto: Mel200 } \\
\text { Allo: Mel200 } \rightarrow 2 \text { Gy TBI }\end{array}$ & $\begin{array}{l}249 \\
91\end{array}$ & $\begin{array}{l}4 \% \\
16 \%\end{array}$ & $\begin{array}{l}41 \% \\
52 \%\end{array}$ & $\begin{array}{l}18 \%(5 y) \\
35 \%(5 y)\end{array}$ & $\begin{array}{l}58 \%(5 y) \\
65 \%(5 y)\end{array}$ & [33] \\
\hline $\begin{array}{l}\text { DSMM } \\
\text { Del13 } \\
\text { HLA-identical } \\
\text { +MUD transplants }\end{array}$ & $\begin{array}{l}\text { Auto: Mel } 200 \mathrm{mg} / \mathrm{m}^{2} \times 2 \\
\text { Allo: } \mathrm{Mel} \rightarrow \text { Mel140/Flu/ ATG }\end{array}$ & $\begin{array}{l}73 \\
126\end{array}$ & $\begin{array}{l}\mathrm{nv} \\
16 \%\end{array}$ & $\begin{array}{l}32 \% \\
59 \%\end{array}$ & $\begin{array}{l}\text { nv } \\
\text { nv }\end{array}$ & $\begin{array}{l}70 \%(3 y) \\
60 \%(3 y)\end{array}$ & [34] \\
\hline
\end{tabular}

1 year), despite in vivo T cell depletion with ATG. Therefore, a selection of unrelated donor is the key factor, and the importance of selecting a matched donor is unavoidable. With these factors combined together, a one-year NRM of less than $10 \%$ was achieved [16].

\section{Graft-versus-myeloma effect and donor lymphocyte infusions (DLI)}

The concept behind allogeneic transplant was to employ the donor's immune process to target MM cells in a process known as graft-versus-myeloma (GVM) effect but this is not inconsequential since it may be associated with GVHD. That being said, cGVHD has been considered a marker for graft-versus-myeloma effect, and many studies have shown this direct relationship. This was reflected as better OS, and PFS when studying the patients with unrelated donors from the Italian Bone Marrow Registry. Crocchiolo et al. (2009) suggest that cGVHD, along with PBSC usage, and the number of chemotherapy rounds before allo HSCT are the factors which have influence upon OS [36]. Similar results were found by Donato with $36.2 \%$ survival advantage at 5 years for the patients with cGVHD [37].

Donor leukocyte infusion was developed in an effort to avoid second transplant in relapsed MM patients following allograft transplant. According to multiple studies, DLI is related to GVM effect and could safely be used to avoid a repeated transplant in relapsed patients. Multiple studies have reported improved PFS and response rate [38-40]. In a re- cently published study, Gröger et al. suggested using DLI as a prophylaxis to avoid relapse and improve remission. After a median follow-up of 68.7 months, they reported good 8-year PFS (43\%) and OS (67\%) following allogeneic transplant in 61 patients who received escalating DLI. Low GVHD incidence was also observed (33\%) with no DLI related mortality [34] in the same reference. On the other hand, Edwin et al. did not observe a difference in the incidence of GVHD when the patients received DLI at less than one year versus $>1$ year after BMT, as shown by Alyea et al. [40, 42]. In terms of DLI dose, some workers suggest lower cell doses for the patients with partial response, or persistent disease after BMT and administering higher doses to those who relapsed after BMT, since higher dosage meant higher GVHD rates, and, therefore, higher toxicity risks $[39,43]$. Ayuk et al. suggests, by using low escalating doses as it is possible, to achieve remission in myeloma patients with relapsed, persistent or progressive disease post BMT [43]. Eefting et al. has found DLI effect to be limited to bone marrow infiltration and not focal progression in multiple myeloma which is defined by new onset or increase in size of plasmacytomas and lytic bone lesions [44].

It is still controversial, whether DLI should be used with novel agents as a prophylaxis to prevent post DLI relapse or not. In fact, Van de Donk et al. proposed application of novel agents, after achieving clinical response in $83.3 \%$ of his patients who did not respond to DLI at the first time and were treated with novel agents after relapse [45]. Meanwhile, Gröger et al. did not find any difference between DLI-treated group and DLI+novel agent groups [39]. 


\section{State of the art: usage of CAR-T cells, autologous and allogeneic SCT in MM}

The idea of recruiting the patient's own cells to fight tumor cells is not a new thing, but the obstacles are also numerous. One of these problems is to make the T cells capable of evading negative selection or central tolerance. This led to the development of affinity-enhanced cells, but it was soon found that their immune escape mechanisms may cause autoimmune disorders. Accordingly, this required a design of cytotoxic cells capable of targeting specifically tumor cells while sparing the normal cells, being a more feasible option, thus leading to design of $\mathrm{T}$ cells with a chimeric antigen receptor (CAR-T cells).

The idea of CAR-T cells was based on potential usage of the patient's own immunity to target malignant cells after genetic reprogramming the effector $\mathrm{T}$ cells, thus enabling them to detect tumor cells without affecting normal human antigens. They are considered a 'living drug, since they tend to persist for long periods of time and eventually result into significant and durable destruction of malignant cells. However, this treatment is still at its early stage of development, and has long way to go, especially, in MM, as the ideal antigen that should be targeted by CAR-T cells is still to be determined.

Broad phenotypic heterogeneity of MM is an obstacle for effective implementation of CAR-T cells. This heterogeneity originates from the various MM subclones that evolve over time within the same patient's cell population, thus making the target antigen selection even more difficult CD138, Igk light chain, and BCMA are considered promising target antigens that were proven to be expressed by MM cells through appropriate screening studies. CD19 can be also exploited as a potential target in leukemia and lymphoma, but not in $\mathrm{MM}$, due to its negligible expression in this disorder [46]. Other antigens, like CD44v6, CD70, CD56, CD38, SLAMF7, were also present on MM cell surface, but no clinical trials were done so far. Unfortunately, most of these antigens, except of BCMA and CD138, are also expressed by other populations, like normal B lymphocytes. Hence, BCMA is the ideal target that was found to be expressed exclusively by MM cells. This was concluded after comparing of MM and normal cells by flow cytometry, IHC, and ELISA techniques, and it was recently supported by 4 clinical trials studying effects of CAR-T cells in 55 patients. Four patients developed complete remission (CR), and 30 patients showed sCR or VGPR [46]. In addition, nine trials were only published as abstracts were conducted to study the efficacy of CAR-T cells in 156 patients. Of them, 31 patients showed complete response, 34 VGPR, and 28 achieved PR [47]. Further studies are essential to analyze $\mathrm{T}$ cell characteristic in MM and detect antigens that could predict response to CAR-T cells in MM patients, as it was the case in CLL. Some antigens were found predictive of good response to CAR-T cells in CLL patients, e.g., immune memory-related genes IL 6 and STAT3 signatures, whereas markers of glycolysis, and effector cell differentiation were found in non-responder group [48]. It is important to keep in mind the cytokine release syndrome which is a common adverse effect of the CAR-T cell therapy. It occurs due to massive production of cytokines like IL6, TNFa, IFNg caused by CAR-T cell activation leading to fever, hypotension, and hypoxia. Fortunately, tocilizumab (an anti IL6 antibody) may counteract the cytokine effect and is used as an off-label drug to control severe cases [49]. Therefore, it is reasonable to monitor the patient closely for at least 9 days, as the reaction appears within days to weeks of treatment initiation. Likewise, potential neurologic toxicity warrants monitoring patients for at least 14 days. The symptoms can range from headache and confusion to hallucinations, or dysphasia and coma [50].

\section{Conclusion}

Over several decades, different treatment options were developed for MM therapy, with gradually increasing success rates. At the present time, where do we stand with cellular therapies in the treatment of Multiple Myeloma?

- Tandem high-dose therapy with autologous stem cell rescue has been a component of several treatment schedules: it is a simple and inexpensive approach which is actively applied with sufficient clinical efficiency. We do not know if it is still an essential component in combination with newer drugs, but do we care? Until proven otherwise, it may stay a part of frontline of MM therapy.

- Allogeneic SCT is a challenging and widely overlooked tool. It has shown curative potential, particularly in relapsed MM. If combined with DLI and immunomodulating agents and minimal residual disease (MRD) tracing, this approach makes immunotherapy a distinct option in MM treatment. To make allogeneic SCT wider applicable and more acceptable, a reduction in TRM is mandatory, like it has been shown feasible in pilot studies.

- The results with CAR-T cells for MM treatment are very preliminary. We need longer observation terms, while looking whether CART cells could be comparable with results of allogeneic HCT. A forthcoming phase III study comparing best available treatment with CAR-T cell therapy in MM should bring a definite answer.

- It is hard to predict the future. It is conceivable, that the plethora of new drugs might override the need for cellular therapies, like we have seen in CML, i.e. control of the disease without aiming for cure.

\section{Conflicts of interest}

None of the authors declare any conflicts of interest.

\section{References}

1. SEER Cancer Statistics Review 1975-2004 - Previous Version - SEER Cancer Statistics. (n.d.). Retrieved from https://seer.cancer.gov/archive/csr/1975_2004/

2. Patriarca F, Einsele H, Spina F, Bruno B, Isola M, Nozzoli C, Nozza A, Sperotto A, Morabito F, Stuhler G, Festuccia M, Bosi A, Fanin R, Corradini, P. Allogeneic stem cell transplantation in multiple myeloma relapsed after autograft: a multi- 
center retrospective study based on donor availability. Biol Blood Marrow Transplant. 2012;18(4): 617-626.

3. Lahuerta JJ, Martinez-Lopez J, Grande C, Bladé J, de la Serna J, Alegre A, García-Laraña J, Caballero D, Sureda A, de la Rubia J, Alvarez AM, Marín J, Escudero A, Conde E, Perez-Equiza K, García Ruiz JC, Moraleda JM, León A, Bargay J, Cabrera R, Hernandez-García MT, Diaz-Mediavilla J, Miguel JS. Conditioning regimens in autologous stem cell transplantation for multiple myeloma: A comparative study of efficacy and toxicity from the Spanish Registry for Transplantation in Multiple Myeloma. Br J Haematol; 2000,109(1):138-147.

4. Martino M, Tripepi G, Messina G, Vincelli ID, Console G, Recchia AG, Gentile M, Molica S, Morabito F. A phase II, single-arm, prospective study of bendamustine plus melphalan conditioning for second autologous stem cell transplantation in de novo multiple myeloma patients through a tandem transplant strategy. Bone Marrow Transplant. 2016;51(9):1197-1203.

5. Capria S, Petrucci MT, Pulsoni A, Ribersani M, Baldacci E, Propris MS, Meloni G. High-dose idarubicin, busulphan and melphalan for autologous stem cell transplantation in multiple myeloma responsive to DAV chemotherapy: comparison with a historical control. Acta Haematol. 2006; 115(1-2): 9-14.

6. Abu Zaid B, Abdul-Hai A, Grotto I, Dray L, Resnick IB, Tsirigotis PD, Samuel S, Or R, Shapira MY. Autologous transplant in multiple myeloma with an augmented conditioning protocol. Leukemia \& Lymphoma. 2013;54(11):2480-2484.

7. Reece D, Song K, LeBlanc R, Mezzi K, Olujohungbe A, White D, Zaman F, Belch A.. Efficacy and Safety of Busulfan-Based Conditioning Regimens for Multiple Myeloma. The Oncologist. 2013,18(5), 611-618.

8. Miller KC, Gertz MA, Buadi FK, Hayman SR, Wolf RC, Lacy MQ, Dispenzieri AA, Dingli D, Kapoor P, Gonsalves WI, Kourelis T, Hogan WJ, Kumar SK.. Comparable outcomes using propylene glycol-free melphalan for autologous stem cell transplantation in multiple myeloma. Bone Marrow Transplant. 2018. doi:10.1038/s41409-018-0302-6.

9. Sivaraj D, Bacon W, Long GD, Rizzieri DA, Horwitz ME, Sullivan KM, Kang Y, Li Z, Chao NJ, Gasparetto C. Highdose BCNU/Melphalan conditioning regimen before autologous stem cell transplantation in newly diagnosed multiple myeloma. Bone Marrow Transplant. 2018; 53(1): 34-38.

10. Attal M, Harousseau JL, Facon T, Guilhot F, Doyen C, Fuzibet JG, Monconduit M, Hulin C, Caillot D, Bouabdallah R, Voillat L, Sotto JJ, Grosbois B, Bataille R; InterGroupe Francophone du Myélome. Single versus double autologous stem-cell transplantation for multiple myeloma. N Engl J Med. 2003;349(26):2495-2502.

11. Kumar SK, Therneau TM, Gertz MA, Lacy MQ, Dispenzieri A, Rajkumar SV, Fonseca R, Witzig TE, Lust JA, Larson DR, Kyle RA, Greipp PR. Clinical course of patients with relapsed multiple myeloma. Mayo Clin Proc 2004;79(7):867874.
12. Atanackovic D, Schilling G. Second autologous transplant as salvage therapy in multiple myeloma. Br J Haematol. 2013;163(5): 565-572.

13. Barlogie B, Mitchell A, Rhee FV, Epstein J, Morgan GJ, Crowley J. Curing myeloma at last: Defining criteria and providing the evidence. Blood 2014;124(20): 3043-3051.

14. Crawley C, Iacobelli S, Bjorkstrand B, Apperley JF, Niederwieser D, Gahrton G. Reduced-intensity conditioning for myeloma: lower non-relapse mortality but higher relapse rates compared with myeloablative conditioning. Blood. 2007; 109: 3588-3594.

15. Bensinger W, Rotta M, Storer B, Chauncey T, Holmberg L, Becker P, Sandmaier BM, Storb R, Maloney D. Allo-SCT for multiple myeloma: a review of outcomes at a single transplant center. Bone Marrow Transplant. 2012; 47(10): 13121317.

16. Cavo M, Rajkumar SV, Palumbo A, Moreau P, Orlowski R, Bladé J, Sezer O, Ludwig H, Dimopoulos MA, Attal M, Sonneveld P, Boccadoro M, Anderson KC, Richardson PG, Bensinger W, Johnsen HE, Kroeger N, Gahrton G, Bergsagel PL, Vesole DH, Einsele H, Jagannath S, Niesvizky R, Durie BG, San Miguel J, Lonial S; International Myeloma Working Group. International Myeloma Working Group consensus approach to the treatment of multiple myeloma patients who are candidates for autologous stem cell transplantation. Blood. 2011; 117(23): 6063-6073.

17. Bruno B, Rotta M, Patriarca F, Mordini N, Allione B, Carnevale-Schianca F, Giaccone L, Sorasio R, Omedè P, Baldi I, Bringhen S, Massaia M, Aglietta M, Levis A, Gallamini A, Fanin R, Palumbo A, Storb R, Ciccone G, Boccadoro M. A comparison of allografting with autografting for newly diagnosed myeloma. New Engl J Med. 2007; 356(11):1110-1120.

18. Rosiñol L, Pérez-Simón JA, Sureda A, de la Rubia J, de Arriba F, Lahuerta JJ, González JD, Díaz-Mediavilla J, Hernández B, García-Frade J, Carrera D, León A, Hernández M, Abellán PF, Bergua JM, San Miguel J, Bladé J; Programa para el Estudio y la Terapéutica de las Hemopatías Malignas y Grupo Español de Mieloma (PETHEMA/GEM). A prospective PETHEMA study of tandem autologous transplantation versus autograft followed by reduced-intensity conditioning allogeneic transplantation in newly diagnosed multiple myeloma. Blood. 2008; 112(9): 3591-3593. doi:10.1182/ blood-2008-02-141598

19. de Lavallade H, El-Cheikh J, Faucher C, Fürst S, Stoppa AM, Coso D, Bouabdallah R, Chabannon C, Gastaut JA, Blaise D, Mohty M. Reduced-intensity conditioning allogeneic SCT as salvage treatment for relapsed multiple myeloma. Bone Marrow Transplant. 2008;41(11):953-960.

20. Gerull S, Goerner M, Benner A, Hegenbart U, Klein U, Schaefer H, Goldschmidt H, Ho AD.. Long-term outcome of nonmyeloablative allogeneic transplantation in patients with high-risk multiple myeloma. Bone Marrow Transplant. 2005; 36(11): 963-969.

21. Nair AP, Walker P, Kalff A, Bergin K, Hocking J, Avery S, Curtis DJ, Patil S, Das T, Klarica D, Morgan S, Muirhead J, Gorniak M, Reynolds J, Spencer A. Adverse impact of high 
donor CD3+ cell dose on outcome following tandem auto-NMA allogeneic transplantation for high-risk myeloma. Bone Marrow Transplant. 2017; 52(6):839-845.

22. Freytes, CO, Vesole, DH, LeRademacher J, Zhong X, Gale RP, Kyle RA, Reece DE, Gibson J, Schouten HC, McCarthy PL, Lonial S, Krishnan AY, Dispenzieri A, Hari, P. N. Second transplants for multiple myeloma relapsing after a previous autotransplant - reduced-intensity allogeneic vs autologous transplantation. Bone Marrow Transplant. 2013; 49(3): 416421.

23. Kröger N, Shimoni A, Schilling G, Schwerdtfeger R, Bornhäuser $M$, Nagler A, Zander AR, Heinzelmann $M$, Brand R, Gahrton G, Morris C, Niederwieser D, de Witte T.. Unrelated stem cell transplantation after reduced intensity conditioning for patients with multiple myeloma relapsing after autologous transplantation. Br J Haematol. 2010; $148(2): 323-331$.

24. Ballen KK, King R, Carston M, Kollman C, Nelson G, Lim S, Reece D, Giralt S, Vesole DH. Outcome of unrelated transplants in patients with multiple myeloma. Bone Marrow Transplant. 2005;35(7):675-681.

25. El-Cheikh J, Crocchiolo R, Boher JM, Furst S, Stoppa AM, Ladaique P, Faucher C, Calmels B, Castagna L, Lemarie C, De Colella JM, Coso D, Bouabdallah R, Chabannon C, Blaise D. Comparable outcomes between unrelated and related donors after reduced-intensity conditioning allogeneic hematopoietic stem cell transplantation in patients with high-risk multiple myeloma. Eur J Haematol. 2012,88(6), 497-503.

26. Donato ML, Siegel DS, Vesole DH, McKiernan P, Nyirenda T, Pecora AL, Baker M, Goldberg SL, Mato A, Goy A, Rowley SD. The graft-versus-myeloma effect: chronic graftversus-host disease but not acute graft-versus-host disease prolongs survival in patients with multiple myeloma receiving allogeneic transplantation. Biol Blood Marrow Transplant. 2014; 20(8): 1211-1216.

27. Green DJ, Maloney DG, Storer BE, Sandmaier BM, Holmberg LA, Becker PS, Fang M, Martin PJ, Georges GE, Bouvier ME, Storb R, Mielcarek M. Tandem autologous/allogeneic hematopoietic cell transplantation with bortezomib maintenance therapy for high-risk myeloma. Blood Adv. 2017; 1(24): 2247-2256.

28. Krishnan A, Pasquini MC, LoganB, Stadtmauer EA, Vesole DH, Alyea E, Antin JH, Comenzo R, Goodman S, Hari P, Laport G, Qazilbash MH, Rowley S, Sahebi F, Somlo G, Vogl DT, Weisdorf D, Ewell M, Wu J, Geller NL, Horowitz MM, Giralt S, Maloney DG, Blood Marrow Transplant Clinical Trials Network (BMT CTN). Autologous haemopoietic stem-cell transplantation followed by allogeneic or autologous haemopoietic stem-cell transplantation in patients with multiple myeloma (BMT CTN 0102): a phase 3 biological assignment trial. Lancet Oncol. 2011;12(13):1195-1203.

29. Björkstrand B, Iacobelli S, Hegenbart U, Gruber A, Greinix H, Volin L, Narni F, Musto P, Beksac M, Bosi A, Milone G, Corradini P, Goldschmidt H, de Witte T, Morris C, Niederwieser D, Gahrton G. Tandem autologous/reduced-intensity conditioning allogeneic stem-cell transplantation versus autologous transplantation in myeloma: long-term follow-up. J Clin Oncol. 2011;29(22):3016-22. doi: 10.1200/ JCO.2010.32.7312

30. Facon T., Mary, J. Y., Hulin, C., Benboubker, L., Attal, M., Pegourie, B., Renaud M, Harousseau JL, Guillerm G, Chaleteix C, Dib M, Voillat L, Maisonneuve H, Troncy J, Dorvaux V, Monconduit M, Martin C, Casassus P, Jaubert J, Jardel H, Doyen C, Kolb B, Anglaret B, Grosbois B, Yakoub-Agha I, Mathiot C, Avet-Loiseau, H.. Melphalan and prednisone plus thalidomide versus melphalan and prednisone alone or reduced-intensity autologous stem cell transplantation in elderly patients with multiple myeloma (IFM 99-06): A randomised trial. Lancet. 2007; 370(9594): 1209-1218.

31. Passera R, Pollichieni S, Brunello L, Patriarca F, Bonifazi F, Montefusco V, Falda M, Montanari M, Guidi S, Giaccone L, Mordini N, Carella AM, Bavaro P, Milone G, Benedetti F, Ciceri F, Scimè R, Benedetti E, Castagna L, Festuccia M, Rambaldi A, Bacigalupo A, Corradini P, Bosi A, Boccadoro M, Bandini G,Fanin R, Bruno B. 2013. Allogeneic hematopoietic cell transplantation from unrelated donors in multiple myeloma: study from the Italian Bone Marrow Donor Registry. Biol Blood Marrow Transplant.2013; 19(6):940948.

32. Goldschmidt H, Lokhorst HM, Mai EK, van der Holt B, Blau IW, Zweegman S, Weisel KC, Vellenga E, Pfreundschuh M, Kersten MJ, Scheid C, Croockewit S, Raymakers R, Hose D, Potamianou A, Jauch A, Hillengass J, Stevens-Kroef M, Raab MS, Broijl A, Lindemann HW, Bos GMJ, Brossart P, van Marwijk Kooy M, Ypma P, Duehrsen U, Schaafsma RM, Bertsch U, Hielscher T, Jarari L, Salwender HJ, Sonneveld P. Bortezomib before and after high-dose therapy in myeloma: long-term results from the phase III HOVON-65/GMMG-HD4 trial. Leukemia 32, 383-390 (2018)

33. Gahrton G, Iacobelli S, Björkstrand B, Hegenbart U, Gruber A, Greinix H, Volin L, Narni F, Carella AM, Beksac M, Bosi A, Milone G, Corradini P, Schönland S, Friberg K, van Biezen A, Goldschmidt H, de Witte T, Morris C, Niederwieser D, Garderet L, Kröger N. Autologous/reduced-intensity allogeneic stem cell transplantation vs autologous transplantation in multiple myeloma: Long-term results of the EBMT-NMAM2000 study. Blood. 2013; 121(25): 5055-5063.

34. Einsele H, Engelhardt M, Tapprich C, Müller J, Liebisch P, Langer C, Kropff M, Mügge LO, Jung W, Wolf HH, Metzner B, Hart C, Gramatzki M, Hertenstein B, Pfreundschuh M, Rösler W, Fischer T, Maschmeyer G, Kanz L, Hess G, Jäger E, Bentz M, Dürk HA, Salwender H, Hebart H, Straka C, Knop S. Phase II study of bortezomib, cyclophosphamide and dexamethasone as induction therapy in multiple myeloma: DSMM XI trial. Br J Haematol. 2017; 179(4), 586-597.

35. Shimoni A, Hardan I, AyukF, Schilling G, Atanackovic D, Zeller W, Yerushalmi R, Zander AR, Kroger N, Nagler A. Allogenic hematopoietic stem-cell transplantation with reduced-intensity conditioning in patients with refractory and recurrent multiple myeloma. Cancer. 2010; 116(15):36213630 .

36. Crocchiolo R, Ciceri F, Fleischhauer K, Oneto R, Bruno B, Pollichieni S, Sacchi N, Sormani MP, Fanin R, Bandini G, Bonifazi F, Bosi A, Rambaldi A, Alessandrino PE, Falda 
M, Bacigalupo A. HLA matching affects clinical outcome of adult patients undergoing haematopoietic SCT from unrelated donors: a study from the Gruppo Italiano Trapianto di Midollo Osseo and Italian Bone Marrow Donor Registry. Bone Marrow Transplant. 2009;44(9):571-577.

37. Donato ML,Siegel DS, Vesole DH, McKiernan P, Nyirenda T, Pecora AL, Baker M, Goldberg SL, Mato A, Goy A, Rowley SD.. The graft-versus-myeloma effect: chronic graftversus-host disease but not acute graft-versus-host disease prolongs survival in patients with multiple myeloma receiving allogeneic transplantation. Biol Blood Marrow Transplant. 2014;20(8):1211-1216.

38. Beitinjaneh AM, Saliba R, Bashir Q, Shah N, Parmar S, Hosing C, Popat U, Anderlini P, Dinh Y, Qureshi S, Rondon G, Champlin RE, Giralt SA, Qazilbash MH. Durable responses after donor lymphocyte infusion for patients with residual multiple myeloma following non-myeloablative allogeneic stem cell transplant. Leukemia Lymphoma. 2012; 53(8):1525-1529.

39. Gröger M, Gagelmann N, Wolschke C, von Pein UM, Klyuchnikov E, Christopeit M, Zander A, Ayuk F, Kröger $\mathrm{N}$. Long-term results of prophylactic donor lymphocyte infusions for patients with multiple myeloma after allogeneic stem cell transplantation. Biol Blood Marrow Transplant. 2018;24(7): 1399-1405.

40. Alyea E, Weller E, Schlossman R, Canning C, Webb I, Doss D, Mauch P, Marcus K, Fisher D, Freeman A, Parikh B, Gribben J, Soiffer R, Ritz J, Anderson K. T-cell-depleted allogeneic bone marrow transplantation followed by donor lymphocyte infusion in patients with multiple myeloma: Induction of graft-versus-myeloma effect. Blood. 2001; 98(4): 934-939.

41. Collins RH Jr, Shpilberg O, Drobyski WR, Porter DL, Giralt S, Champlin R, Goodman SA, Wolff SN, Hu W, Verfaillie C, List A, Dalton W, Ognoskie N, Chetrit A, Antin JH, Nemunaitis J. Donor leukocyte infusions in 140 patients with relapsed malignancy after allogeneic bone marrow transplantation. J Clin Oncol. 1997;15(2):433-444.

42. Alyea E, Weller E, Schlossman R, Canning C, Webb I, Doss D, Mauch P, Marcus K, Fisher D, Freeman A, Parikh B, Gribben J, Soiffer R, Ritz J, Anderson K. Graft-versus-leukemia effect of donor lymphocyte transfusions in marrow grafted patients. Blood. 2001; 98:934-939.

43. Ayuk F, Shimoni A, Nagler A, Schwerdtfeger R, Kiehl M, Sayer HG, Zabelina T, Zander AR, Kröger N. Efficacy and toxicity of low-dose escalating donor lymphocyte infusion given after reduced intensity conditioning allograft for multiple myeloma. Leukemia. 2004; 18(3):659-662.

44. Eefting M, de Wreede LC, Von dem Borne PA, Halkes CJM, Kersting S, Marijt EWA, Putter H, Veelken H, Schetelig J, Falkenburg JHF. Donor T-cell responses and disease progression patterns of multiple myeloma. Bone Marrow Transplant. 2017;52(12):1609-1615.

45. van de Donk NW, Kröger N, Hegenbart U, Corradini P, San Miguel JF, Goldschmidt H, Perez-Simon JA, Zijlmans M, Raymakers RA, Montefusco V, Ayuk FA, van Oers MH,
Nagler A, Verdonck LF, Lokhorst HM. Prognostic factors for donor lymphocyte infusions following non-myeloablative allogeneic stem cell transplantation in multiple myeloma. Bone Marrow Transplant. 2006; 37(12):1135-1141.

46. Carpenter RO, Evbuomwan MO, Pittaluga S, Rose JJ, Raffeld M, Yang S, Gress RE, Hakim FT, Kochenderfer JN. B-cell maturation antigen is a promising target for adoptive T-cell therapy of multiple myeloma. Clin Cancer Res. 2013;19(8):2048-2060.

47. Danhof S, Hudecek M, Smith EL. CARs and other T cell therapies for MM: The clinical experience. Best Pract Res Clin Haematol. 2018; 31(2): 147-157.

48. Fraietta JA, Lacey SF, Orlando EJ, Pruteanu-Malinici I, Gohil M, Lundh S, Boesteanu AC, Wang Y, O'Connor RS, Hwang WT, Pequignot E, Ambrose DE, Zhang C, Wilcox N, Bedoya F, Dorfmeier C, Chen F, Tian L, Parakandi H, Gupta M, Young RM, Johnson, FB, Kulikovskaya I, Liu L, Xu J, Kassim SH, Davis MM, Levine BL, Frey NV, Siegel D L, Huang AC, Wherry EJ, Bitter H, Brogdon JL, Porter DL, June CH, Melenhorst JJ. Determinants of response and resistance to CD19 chimeric antigen receptor (CAR) T cell therapy of chronic lymphocytic leukemia. Nature Med. 2018; 24(5): 563-571.

49. Kenderian SS, Ruella M, Gill S, Kalos M. Chimeric Antigen Receptor T-cell Therapy to Target Hematologic Malignancies. Cancer Res. 2014,74(22), 6383-6389.

50. Brudno JN, Kochenderfer JN. Toxicities of chimeric antigen receptor T cells: Recognition and management. Blood. 2016;127(26), 3321-3330. 


\title{
Трансплантация стволовых гемопоэтических клеток и возможная роль CAR T-клеток при лечении миеломной болезни
}

\author{
Нуран Саббах ${ }^{1}$, Аксель Р. Цандер ${ }^{2,3}$ \\ ${ }^{1}$ Университет Аль-Фейсал, Эр-Риад, Саудовская Аравия \\ ${ }^{2}$ Отдел трансплантации стволовых клеток, Центр раковых исследований Хантсманна, Солт-Лейк-Сити, США \\ ${ }^{3}$ Гамбургский Университет, Гамбург, Германия
}

\section{Резюме}

Миеломная болезнь (МБ) остается пока неизлечимым злокачественным заболеванием, не отвечающим в полной мере на множество видов химио- и иммунотерапевтических методов лечения. В США ежегодно диагностируются более 20000 случаев. Трансплантация костного мозга все еще рассматривается как основной метод лечения МБ, по крайней мере в настоящее время. Очевидной необходимостью является повторное рассмотрение старых подходов к лечению с применением клеточной терапии, таких, как аутологичная или аллогенная трансплантация гемопоэтических стволовых клеток (ТГСК) и разработка новых опций, таких, как использование CAR-T-клеток.
Эта обзорная статья будет оценивать и обсуждать различные современные подходы к лечению МБ, путем обобщения результатов клинических исследований, рассматривать вопросы выполнимости и эффективности, и искать ответы на те из них, которые уже решены в ходе ряда клинических испытаний, проведенных с введением CAR T-клеток.

\section{Ключевые слова}

Множественная миелома, аллогенная трансплантация, аутологичная трансплантация, CAR T-клетки. 